\title{
Analisis Jumlah Produksi Kerudung Pada RAR Azkia Bandung Dengan Metode Economic Production Quantity (EPQ)
}

\author{
Farid H Badruzzaman ${ }^{1}$, Erwin Harahap ${ }^{2}$, Eti Kurniati ${ }^{3}$, M. Deni Johansyah ${ }^{4}$ \\ 1,2,3 Program Studi Matematika, FMIPA, Universitas Islam Bandung \\ ${ }^{4}$ Departemen Matematika, FMIPA, Universitas Padjadjaran \\ faridhb@unisba.ac.id,erwin2h@unisba.ac.id,eti_k@unisba.ac.id,muhamad.deni@unpad.ac.id
}

\begin{abstract}
Abstrak. Permasalahan dari persediaan adalah bagaimana menentukan jumlah produksi optimal dengan biaya total persediaan yang minimum. Sebuah persediaan dilakukan tidak lain dengan maksud mengantisipasi dan memenuhi permintaan yang akan datang. Penyimpanan persediaan dalam jangka waktu yang lama akan berdampak pada keusangan dan menurunnya kualitas, sehingga diperlukan perhitungan jumlah persediaan yang optimal. Model persediaan Economic Production Quantity (EPQ) merupakan suatu metode yang digunakan untuk mempertimbangkan jumlah produksi dan jumlah permintaan hasil produksi. Tujuannya adalah dengan menentukan banyaknya produksi yang meminimumkan total biaya persediaan. Penelitian ini bertujuan untuk menghitung jumlah produksi optimum pada perusahaan kerudung. Selama ini, jumlah produksi pada tahun 2017 dan sebelumnya berpedoman pada jumlah pesanan pelanggan ditambah 17,5\% dari jumlah permintaan untuk cadangan persediaan. Hasil solusi optimum dengan model EPQ memiliki perbedaan yang signifikan dibandingkan dengan yang selama ini berlaku.
\end{abstract}

Kata Kunci: economic production quantity, persediaan, produksi

\begin{abstract}
The problem of inventory is how to determine the optimal amount of production with minimum total inventory cost. An inventory is carried out with no other intent to anticipate and meet future demand. Storage of inventory over a long period of time will have an impact on obsolescence and declining quality, so it is necessary to calculate the optimal amount of inventory. Model inventory Economic Production Quantity (EPQ) is a method used to consider the number of production and the number of production demand. The goal is to determine the amount of production that minimizes the total cost of inventory. This study aims to calculate the number of optimum production on the company's hood. So far, the number of production in 2017 and previously guided by the number of customer orders plus $17.5 \%$ of the total demand for inventory reserves. The results of the optimum solution with the EPQ model have significant differences compared to those currently in force.
\end{abstract}

Keywords: economic production quantity, inventory, production

\section{Pendahuluan}

Salah satu tujuan perusahaan adalah untuk memperoleh keuntungan dan menjaga keberlangsungan usahanya. Ada beberapa faktor penting yang mempengaruhi pencapaian tujuan perusahaan, salah satunya adalah kelancaran proses produksi. Proses produksi merupakan kegiatan untuk menambah kegunaan suatu barang dengan memanfaatkan sumber daya, baik bahan baku, sumber daya manusia dan peralatan produksi lainnya. Melalui proses produksi, perusahaan mengolah bahan baku menjadi produk yang dapat dijual kepada masyarakat, guna mendapatkan keuntungan. Proses produksi yang berjalan lancar akan mendukung pencapaian tujuan perusahaan. Sebaliknya, peroses produksi yang terhambat, akan menyebabkan pencapaian tujuan perusahaan akan terhambat pula, sehingga dapat menyebabkan kerugian. 
Persediaan merupakan faktor utama di dalam sebuah perusahaan dan dapat didefinisikan sebagai barang yang disimpan untuk digunakan atau dijual pada periode mendatang. Model EPQ (Economic Order Quantity) merupakan suatu metode yang digunakan untuk mempertimbangkan jumlah produksi dan jumlah permintaan hasil produksi.

Bagi perusahaan yang memproduksi barang umumnya penetapan jumlah produksi didasarkan pada pesanan konsumen. Oleh karena itu, perusahaan, harus memperhitungkan tingkat persediaan serta perkiraan penjualan produk. Bila terdapat ketidaktepatan dalam menentukan jumlah produksi, maka akan mengakibatkan kekurangan jumlah produksi atau kelebihan jumlah produksi, sehingga menimbulkan persediaan yang menumpuk. Penumpukan persediaan akan menyebabkan adanya penambahan biaya persediaan serta kemungkinan terjadinya keusangan dan kualitas yang tidak bisa dipertahankan, sehingga akan dapat mengurangi laba perusahaan. Sebaliknya kekurangan produksi akan mengakibatkan kemacetan dalam proses penjualan, sehingga keuntungan yang bisa diperoleh perusahaan akan berkurang. Oleh karena itu perusahaan perlu menghitung jumlah produksi dengan tepat agar jumlah produksi tidak terlalu banyak atau terlalu sedikit, sehingga memiliki persediaan yang optimal. Kondisi seperti ini bisa melancarkan operasi perusahaan dalam jumlah, waktu, mutu yang tepat serta biaya yang serendah-rendahnya sehingga bisa memaksimalkan laba/keuntungan perusahaan.

\section{Tinjauan Pustaka}

Persediaan dapat diartikan sebagai stock barang-barang yang disimpan oleh organisasi untuk memenuhi permintaan pelanggan. Perumusan EOQ yaitu dengan mencari biaya total (Total Cost) di mana parameternya yaitu jumlah dari biaya simpan, biaya pesan dan biaya pembelian. Biaya pembelian merupakan perkalian antara jumlah barang dan harga per unitnya. Biaya pesan merupakan perkalian antara frekuensi pemesanan dan biaya pesan.

Model EPQ (Economic Order Quantity) merupakan suatu metode yang digunakan untuk mempertimbangkan jumlah produksi dan jumlah permintaan hasil produksi. Pada model persediaan ini, jumlah produksi harus lebih besar dari pada jumlah permintaan. Jumlah persediaan akan bertambah secara bertahap dan juga berkurang secara bertahap untuk memenuhi permintaan dan tidak akan terjadi kekurangan persediaan karena permintaan selalu terpenuhi.

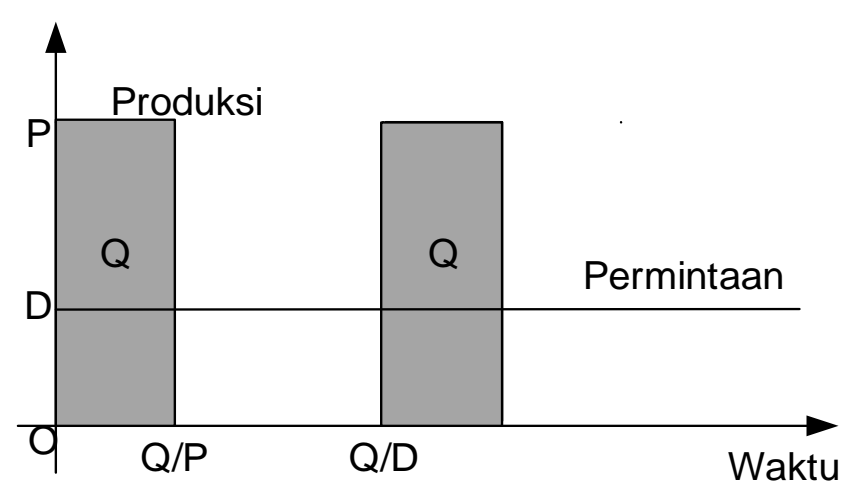

Gambar 1 


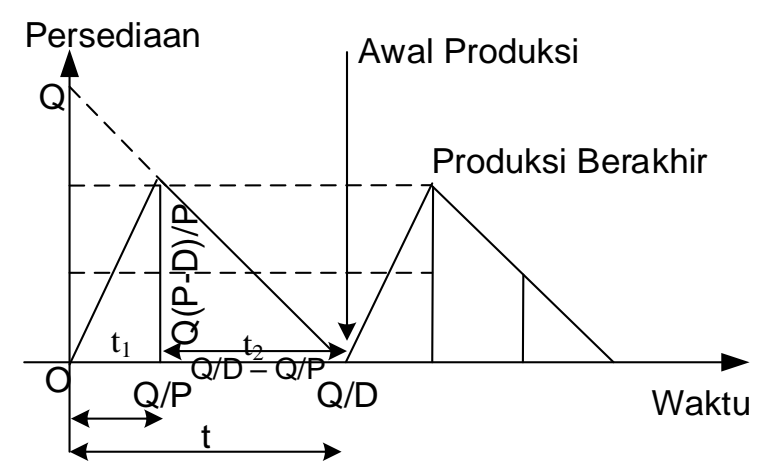

Gambar 2.

Dari gambar 1 dan 2 di atas, dapat dijelaskan bahwa jumlah produksi dalam waktu t harus memenuhi jumlah permintaan $D$, sehingga $Q=D t$.

Tingkat produksi pada interval waktu $\left[0, \mathrm{t}_{1}\right]$ adalah sebesar $P$, sehingga jumlah produksi adalah $Q=t_{1} . P$, atau $t_{1}=\frac{Q}{P}$. Selama periode produksi dinyatakan bahwa tingkat produksi $(\mathrm{P})$ harus memenuhi permintaan (D), sehingga haruslah $P>D$. Seiring dengan berjalannya waktu dan permintaan, tingkat pertambahan persediaan adalah sebesar $P-D$. Pada interval waktu $\left[\mathrm{t}_{1}, \mathrm{t}_{2}\right]$ proses produksi berhenti dan permintaan berlangsung terus sebesar D sampai persediaan mencapai nol. Pada saat produksi berhenti, tingkat persediaan adalah $\frac{Q(P-D)}{P}$. Besarnya rata-rata persediaan itu adalah

$$
\frac{Q}{P} \cdot \frac{(P-D)}{2} \cdot \frac{Q}{P} \cdot \frac{(P-d)}{2}=\frac{Q P-Q d}{2 P}=\frac{Q}{2}-\frac{Q d}{2 P}=\frac{Q}{2}\left(1-\frac{d}{P}\right)
$$

Jika $\mathrm{C}_{1}$ adalah biaya penyimpanan, maka biaya rata-rata penyimpanan adalah $\frac{Q}{2}\left(1-\frac{d}{P}\right) C_{1}$. Karena jumlah putaran produksi adalah $\frac{D}{Q}$, maka besar biaya pemesanan adalah $\frac{D}{Q} C_{2}$. Jadi, jumlah biaya total persediaan adalah

$$
T C=\frac{D}{Q} C_{2}+\frac{Q}{2}\left(1-\frac{D}{P}\right) C_{1}
$$

Selanjutnya akan dicari jumlah produksi optimum. Untuk itu, ambil turunan pertama

$$
T C=\frac{D}{Q} C_{2}+\frac{Q}{2}\left(1-\frac{D}{P}\right) C_{1}
$$

terhadap Q, maka 


$$
\frac{d T C}{d Q}=-\frac{D}{Q^{2}} C_{2}+\frac{1}{2}\left(1-\frac{D}{P}\right) C_{1}=0
$$

$$
\begin{aligned}
& \frac{D}{Q^{2}} C_{2}=\frac{1}{2}\left(1-\frac{D}{P}\right) C_{1} \\
& Q^{2}\left(1-\frac{D}{P}\right) C_{1}=2 D C_{2}
\end{aligned}
$$

$$
Q_{\text {opt }}=\sqrt{\frac{2 D C_{2}}{\left(1-\frac{D}{P}\right) C_{1}}}
$$

Jadi, total biaya persediaan minimum dapat dicari dengan persamaan

$$
T C_{o p t}=\frac{D}{Q_{o p t}} C_{2}+\frac{Q_{o p t}}{2}\left(1-\frac{D}{P}\right) C_{1}
$$

Selanjutnya untuk menunjukkan bahwa tingkat persediaan itu adalah minimum, ambil turunan ke dua dari persamaan (1) terhadap Q:

$$
\frac{d^{2} T C}{d Q^{2}}=2 \frac{D}{Q^{3}} C_{2}
$$

Persamaan terakhir ini selalu positif untuk $\left\{\mathrm{Q}, \mathrm{D}, \mathrm{C}_{2}\right\} \in \mathfrak{N}>0$. Ini menunjukkan bahwa total biaya persediaan adalah minimum. Untuk menghitung biaya persediaan optimum adalah dengan mensubstitusikan persamaan (2) terhadap

$$
T C_{o p t}=\frac{D}{Q_{o p t}} C_{2}+\frac{Q_{o p t}}{2}\left(1-\frac{D}{P}\right) C_{1}
$$

Dengan :

TC : Total biaya persediaan

D : Besarnya permintaan

Q opt : Jumlah produksi optimum

$\mathrm{C}_{2} \quad$ : Biaya persiapan atau pemesanan

$\mathrm{P} \quad$ : Jumlah produksi

$\mathrm{C}_{1} \quad$ : Biaya penyimpanan

\section{Hasil dan Pembahasan}

Perhitungan jumlah produksi saat ini berpedoman pada jumlah pesanan konsumen ditambah $17,5 \%$ dari pesanan untuk cadangan persediaan. Berikut ini disajikan tabel 1 , jumlah permintaan setiap bulan. 
Tabel 1 Jumlah Permintaan Kerudung Tahun 2017

\begin{tabular}{|c|l|l|l|}
\hline No & \multicolumn{1}{|c|}{ Bulan } & \multicolumn{1}{|c|}{$\begin{array}{c}\text { Jumlah Permintaan } \\
\text { (dalam Kodi) }\end{array}$} & \multicolumn{1}{|c|}{$\begin{array}{c}\text { Penambahan Jumlah Produk } \\
\text { (dalam Kodi) }\end{array}$} \\
\hline 1 & Januari & 3400 & 595 \\
\hline 2 & Februari & 3225 & 564,375 \\
\hline 3 & Maret & 3650 & 297,70625 \\
\hline 4 & April & 3900 & 468,0625 \\
\hline 5 & Mei & 4050 & 365,0625 \\
\hline 6 & Juni & 4200 & 187,74375 \\
\hline 7 & Juli & 4125 & 450,45 \\
\hline 8 & Agustus & 4150 & 508,14063 \\
\hline 9 & September & 4000 & 383,04375 \\
\hline 10 & Oktober & 3600 & 207 \\
\hline 11 & Nopember & 3500 & 210.65 \\
\hline 12 & Desember & 3650 & 206,9375 \\
\hline & & $\mathbf{4 5 4 5 0}$ & $\mathbf{3 8 4 9 , 1 7 1 8 8}$ \\
\hline
\end{tabular}

Jumlah permintaan dalam satu tahun adalah sebanyak 45450 kodi, dengan rata-rata perbulan adalah 3787,5 kodi.

Tabel 2 Jumlah Produksi Kerudung Tahun 2017

\begin{tabular}{|c|c|c|c|c|}
\hline No & Bulan & $\begin{array}{l}\text { Jumlah Produksi } \\
\text { (kodi) }\end{array}$ & Terjual (kodi) & Sisa (kodi) \\
\hline 1 & Januari & 3995 & 3430,625 & 564,375 \\
\hline 2 & Februari & 3789,375 & 3448,33125 & 341,04375 \\
\hline 3 & Maret & 4288,75 & 4074,3125 & 214,4375 \\
\hline 4 & April & 4582,5 & 4238,8125 & 343,6875 \\
\hline 5 & Mei & 4758,75 & 4211,49375 & 547,25625 \\
\hline 6 & Juni & 4935 & 4663,575 & 271,425 \\
\hline 7 & Juli & 4846,875 & 4628,76563 & 218,10937 \\
\hline 8 & Agustus & 4876,25 & 4559,29375 & 316,95625 \\
\hline 9 & September & 4700 & 4277 & 423 \\
\hline 10 & Oktober & 4230 & 3828,15 & 401,85 \\
\hline 11 & Nopember & 4112,5 & 3680,6875 & 431,8125 \\
\hline 12 & Desember & 4288,75 & 3752,65625 & 536,09375 \\
\hline & Jumlah & 53403,75 & 48793,70313 & 4610,04687 \\
\hline
\end{tabular}

Total produksi pada tahan 2017 adalah 53403,75 kodi dan rata-rata produksi setiap bulannya adalah 4609,4271 kodi. Total jumlah kerudung yang terjual adalah 48793,70313 kodi sedangkan jumlah kelebihan produksinya adalah 4610,04687 kodi.

Biaya persiapan pemesanan selama tahun 2017 adalah Rp. 15.250.000,- biaya sarana komunikasi dan administrasi adalah Rp. 27.770.000,- dan biaya pengiriman adalah Rp. 9.700.000,-- Total semua biaya pemesanan adalah Rp. 52.720.000,- dan rata-rata biaya per bulannya adalah Rp. 4.393.333,-Untuk biaya penyimpanan jumlah kerudung yang belum terjual ditetapkan sebesar $8,75 \%$ dari harga jual, yaitu sebesar Rp. 28.000,-. Sehingga jumlah biaya persediaan yaitu 3849,17188 x Rp.28.000,- = 
Rp. 107.776.812,64,- dengan rata-rata perbulannya adalah Rp. 8.981.401,0533,-. Perhitungan jumlah produksi berdasarkan EPQ

$$
\begin{aligned}
& Q_{\text {opt }}=\sqrt{\frac{2 D C_{2}}{\left(1-\frac{D}{P}\right) C_{1}}} \\
& Q_{j a n}=\sqrt{\frac{2(3400)(4.393 .333)}{\left(1-\frac{3400}{3995}\right) 14000}}=\sqrt{\frac{29.874 .664 .400}{2085,106}}=\sqrt{14.327 .645,17}=3785,188 \\
& Q_{p e b}=\sqrt{\frac{2(3225)(4.393 .333)}{\left(1-\frac{3225}{3789,375}\right) 14000}}=\sqrt{\frac{28.336 .997 .850}{2085,106}}=\sqrt{13.590 .195,343}=3686,488
\end{aligned}
$$

Dengan cara perhitungan yang sama untuk jumlah produksi bulan-bulan berikutnya, perhitungan EPQ dan hasilnya seperti tampak pada tabel 3 di bawah ini.

Tabel 3 Hasil Perhitungan EPQ

\begin{tabular}{|l|l|l|}
\hline No & Bulan & $\begin{array}{l}\text { Jumlah Produksi (dalam } \\
\text { Kodi) }\end{array}$ \\
\hline 1 & Januari & 3785,188 \\
\hline 2 & Februari & 3686,488 \\
\hline 3 & Maret & 3921,881 \\
\hline 4 & April & 4053,967 \\
\hline 5 & Mei & 4131,193 \\
\hline 6 & Juni & 4207,001 \\
\hline 7 & Juli & 4169,269 \\
\hline 8 & Agustus & 4181,884 \\
\hline 9 & September & 4105,612 \\
\hline 10 & Oktober & 3894,926 \\
\hline 11 & Nopember & 3840,449 \\
\hline 12 & Desember & 3921,881 \\
\hline & & $\mathbf{4 7 8 9 9 , 7 4}$ \\
\hline
\end{tabular}

Berikut ini disajikan rincian hasil perhitungan total biaya perbulan.

Untuk bulan Januari :

$$
T C_{j a n}=\frac{3400}{3785,188}(4393333)+\frac{3785,188}{2}\left(1-\frac{3400}{3995}\right) 14000=7.892 .518,827
$$

Untuk bulan Februari :

$$
T C_{F e b}=\frac{3225}{3785,188}(4393333)+\frac{3785,188}{2}\left(1-\frac{3225}{3995}\right) 14000=7.686 .719,397
$$

Dengan cara yang sama untuk menghitung biaya persediaan pada bulan berikutnya diperoleh seperti tampak pada tabel 4 berikut ini: 
Tabel 4 Biaya Persediaan Tahun 2017

\begin{tabular}{|l|l|l|}
\hline No & Bulan & Biaya (Rupiah) \\
\hline 1 & Januari & $7.892 .518,827$ \\
\hline 2 & Februari & $7.686 .719,397$ \\
\hline 3 & Maret & $8.177 .538,552$ \\
\hline 4 & April & $8.452 .953,337$ \\
\hline 5 & Mei & $8.613 .976,440$ \\
\hline 6 & Juni & $8.772 .044,238$ \\
\hline 7 & Juli & $8.693 .369,607$ \\
\hline 8 & Agustus & $8.719 .673,357$ \\
\hline 9 & September & $8.560 .638,612$ \\
\hline 10 & Oktober & $8.121 .334,872$ \\
\hline 11 & Nopember & $8.007 .744,175$ \\
\hline 12 & Desember & $8.177 .538,552$ \\
\hline & & $\mathbf{9 9 . 8 7 6 . 0 4 9 , 9 7}$ \\
\hline
\end{tabular}

Dari hasil pengolahan data, total biaya persediaan pertahun dengan menggunakan metoda EPQ, yaitu

$$
T C_{o p t}=\frac{D}{Q_{o p t}} C_{2}+\frac{Q_{o p t}}{2}\left(1-\frac{D}{P}\right) C_{1}
$$

adalah Rp. 99.876.049,97

Perhitungan pada saat ini (sebelum menggunakan EPQ) :

Total biaya persediaan saat ini (per tahun) adalah 3849,17188 kodi x Rp.28.000 = Rp.107.776.812,64. Apabila dibandingkan biaya persediaan saat ini dan dengan menggunakan metoda EPQ, ada selisih (pengurangan biaya persediaan) sebesar Rp.7.900.762,67. Hasil selisih biaya persediaan ini bisa mengurangi biaya persediaan, sehingga bisa menambah keuntungan/laba perusahaan.

\section{Kesimpulan}

Beberapa kesimpulan dapat ditarik adalah:

1. Model EPQ (Economic Order Quantity) merupakan suatu metode yang digunakan untuk mempertimbangkan jumlah produksi dan jumlah permintaan hasil produksi.

2. Dibandingkan dengan model yang selama ini dipakai, hasil solusi dengan model Economic Production Quantity (EPQ) memiliki perbedaan signifikan yang diperlihatkan dengan adanya pengurangan biaya persediaan.

\section{Referensi}

1. Hidayat, Ratih M. dkk; Model EOQ Untuk Permintaan Bergantung Waktu Dengan Mempertimbangkan Laju Kerusakan. Jurnal Matematika UNISBA Vol. 1 No. 1, Agustus 2016 http://ejournal.unisba.ac.id

2. Murthy, P Rama, (2007) Operations Research, New Age International (P) Ltd., Publishers, New Delhi

3. Sibarani, Elisabeth dkk, Penggunaan Metode EOQ Dan EPQ

Dalam Meminimumkan Biaya Persediaan Minyak Sawit 
Mentah (CPO) (Studi Kasus : Pt. XYZ), Saintia Matematika

Vol. 1, No. 4 (2013), pp. 337-347.

4. Soraya, Ira. Model Persediaan Economic Production Quantity (EPQ) dengan mempertimbangkan deteriorasi. Jurnal Matematika UNAND Vol.3 No.3 Hal. 50-58

5. Taha, Hamdy A. (2003) Operations Research. Seventh Edition. Pearson Education International Inc. Prentice Hall.

6. Waters, Donald, (2003); Inventory Control and Management, John Wiley \& Sons Ltd, The Atrium, Southern Gate, Chichester, West Sussex PO19 8SQ, England. 